\title{
The Power of the Periphery: Circulation of Cross-Cultured Languaging Through the Importation of Francophone Comics in the Nation-State of Sweden, 1900-2020
}

\author{
Ylva Lindberg \\ Professor of Education, Language and Literature, School of Education and \\ Communication, Jönköping University, Jönköping, Sweden \\ ylva.lindberg@ju.se
}

\begin{abstract}
The objective with this study is to shed light upon how international exchanges on the comic art market contribute to democratization processes and renegotiation of hegemonies in the literary field worldwide. The focus is on how the variation in imported comics from a central language, in this case French, to the peripheral space of Sweden, can be observed during the time-period 1900-2020, as well as on which diversity importation of comics has been allowed over time. Theoretically anchored in sociological perspectives in literary studies highly influenced by Casanova's ([1999]2004) seminal work, this contribution challenges established approaches in the field that depart from central cultural spaces in the world. Instead, this analysis highlights how the periphery gains agency on the international market and challenges relations of domination through translation practices. One hypothesis put forward consists of the idea that Francophone author-illustrators from the global South would be identifiable in the data in 199o's, as is the case in the literary field. However, in the comics field this change emerges later, and does not appear distinctively until 2005 . The change is paired with a promotion of Francophone female author-illustrators in Swedish translations, equally from the global South and the global North. The results also highlight that Sweden positions the Francophone space as hyper-central within the comics field. The specific practices adopted in the importation point to how a periphery creates agency to define a medium and a genre locally and play a role in international cultural exchanges.
\end{abstract}




\section{Keywords}

comic art - literature - translation - Sweden - Francophone - diversity

\section{Introduction}

This study departs from the assumption that the concepts "languaging" (BaggaGupta 2019), "diversity", and "democracy" could usefully be clarified through the study of comic art, and how this cultural expression emerges in translation endeavors over time in a cultural space in the global North where the comic art market is evolving. This exploration is delimited to the exchange between Francophone and Swedish cultural spaces in the timespan 1900-2020.

Comics offer possibilities for studying languaging features at several different levels, for example, regarding authorship identity, the format, visual representations, the relationship between text and image, as well as socio-linguistic traits, regarding accents, dialects, jargon, and group identity (Bramlett 2012). In addition, in the 2oth century, comic art has a history of diversification, pointing to a multitude of nascent genres, such as comic strips, comix, graphic novels, comic books, webcomics, and manga (Hatfield \& Beaty 2020). This evolution of expressions has not only led to a multidisciplinary scholarship, but also to an ambiguous status of comics, situated in-between a genre and a medium (Berndt 2016). In this specific study, comics are conceived of as a medium that can embrace a range of genres and formats. The openness towards a variety of cultural and languaging expressions, as well as to innovative combinations of storytelling modes, both texts, images, and sounds, makes comic art subject to narrative complexity that places it "on equal footing with text-based literature" (Kennedy et al. 2015, p. 187; see also Kukkonen 2013). Through artistic and intellectual innovations, comics have progressively approached the literary field. The first album about Corto Maltese, Albi di Corto Maltese (1967) [Eng: The Ballad of the Salty Sea, 2020. $]^{1}$ by the Italian author-illustrator Hugo Pratt is often put afore as a premier in the comic art literary vein, followed by works like A Contract with God (1978) by the Jewish-American author-illustrator and comics theorist Will Eisner, and the widespread story of Maus (1986 first volume, 1991 second volume) by the

1 Titles in other languages than English, such as Italian in this case, and French and Swedish throughout the article, are also mentioned in English. The English titles are mentioned with the first year of publication in cases where Francophone comics series have been translated into English. If there is no published English translation to be found, the English title is my translation. 
Jewish-American cartoonist Art Spiegelman (see Federici 2019). Aesthetically and communicatively groundbreaking, these examples nevertheless consolidate a complicity between Northern central (male) perspectives and a global literary norm, possibly hindering the circulation of a plurality of expressions, including the margins. Hence, the diversity that the comic art medium has the potential to produce and is generating in several cultural spaces (see, for example, Berninger 2010), is apparently not a guarantee for circulation and inclusion on a global level of diverse cultural connections and voices.

Even though the western world has dominated the international comic art market during the 2oth century, around the millennium shift, a hegemonical change has unfolded, without a counterpart in the literary field. In fact, the international establishment of Japanese manga as an equal concurrent to Francophone bande dessinées [comics] and American comics has allowed for an Asian space to enter the global stage as a cultural gatekeeper and a productive center that exports manga to the world. Through prestigious awards, Japan has risen to the status of decision-maker regarding aesthetical values, thus, determining which author-illustrators are worthy to promote on the global arena. This change of scenery tends to offer more visibility to peripheral languages and cultural spaces where comics are thriving, though not circulating on a global level (Lindberg 2018a; 2018b). In this perspective, translation practices play an important role for crossing borders and for communication across different geopolitical regions. Translation could most probably form a leverage for improved democratic representation across the global South and the global North if translation studies and practices were considered more often in democratization and decolonial endeavors.

This study's inscription in translation studies is partly motivated by a need for recognition of translation efforts and academic achievements in the field. Scholars from nation-states with low exportation and high importation rate of literature have progressively taken the lead in these endeavors, with the aim to draw the attention to how, principally, minor languages are contributing to the improvement of translations worldwide (Zlatnar Moe, Žigon and Mikolič Južnič 2019). The conceptual pair of peripheries/centers is closely related to minor/major (or dominated/dominant) languages, since a minority position most often propels a language towards the outskirts of the cultural arena (the periphery), both in a symbolic way, through the dearth of "cultural capital" (Bourdieu 2008; [1986] 2011), and in a geopolitical way, where the minority position is overlooked, either by ignorance or by calculated acts that serve the purpose of maintaining frontiers between peripheries and centers (see Burnautzki 2017). Central languages, in turn, are reinforced, not only by the number of primary speakers, and political, cultural, and economic powers, 
but, as literature scholar Pascale Casanova (2010) has pointed out, through the number of polyglots using the language for various purposes (see also de Swann 1993), such as accessing literature and comic art originating from different languages. The power positions and the relationships between cores and peripheries in the global system of literature in circulation are not fixed, ${ }^{2}$ but rather in movement and constantly negotiated, for example through translation endeavors.

In Johan Heilbron's (1999) analysis, four categories of languaging positionings are identified based on the share of the literary world market (see, for example, UNESCO's Index translationum, http://www.unesco.org/xtrans/). This effort to regroup languages from a literary production perspective sometimes stands in stark contrast to the actual number of speakers. For example, Chinese and Arabic languages become peripheral in this model. Heilbron's (1999) categories are outlined as hyper-central languages (currently English language), central languages (among which we find French language varieties), semi-peripheral languages (among which we find Swedish), and peripheral languages (for example Chinese, Arabic, and Hindi).

Even though Swedish is categorized as a semi-peripheral language according to this model, a nation-state can very well be peripheral regarding reception and exchange of a specific medium and genre, which would be applicable to the case of Sweden. The nation-state of Sweden has imported comics since the beginnings of the 2oth century, but exportation did not take off until female author-illustrators received permission from the male establishment at the local comic market to get published. This shift also led to wider comic readership groups (Lindberg 2014; 2016; 2018b). Moreover, demographically, Sweden is considered an "immigration country" (Statistics Sweden 2018: 82) since the immigration rate steadily remains higher than the average of OECD nations. In addition, the main immigrants come from cultural spaces outside of Europe (Statistics Sweden 2018), which calls for production of cultural expressions that can reflect the internal diversity, as well as that of the world.

In the global literary exchange system, cultural spaces in the margins, such as Sweden, are "intersected and altered by another culture (from the core)"

2 The view of global literary exchange and translation as a system is transposed from sociological research in world-system theory, where Immanuel Wallerstein's seminal work on world relations in the 1970's constitutes the ground for research on exchanges in the cultural sector (Wallerstein 2004). 
(Moretti 2013: 47), such as the Francophone space, that "completely ignores it" (Even-Zohar 1990: 54, 62). If dominating centers on the comic art market choose to remain ignorant, or, perhaps, indifferent vis-à-vis expressions from the margins, it is vital for local and peripheral markets to adopt a vigilant attitude with regards to which comics are selected, imported, and mediated. It is noteworthy that "the role of literary translations is never merely peripheral or even marginal, as they are key to the shaping and reshaping of national languages" (Zlatnar Moe, Žigon and Mikolič 2019: 25). As will be observed in the present study, translation and the necessary selection that precedes it also participate in the shaping and reshaping of a medium and its genres in global circulation, in this case comic art. In fact, the periphery's potential agency to redistribute symbolic capital and participate in recognizing the diversity of comics is at stake here. The development of an awareness of factors that affect incoming flows of cultural artefacts to a local cultural space carries opportunities for acute critical reception of the same, which, in turn, can raise issues regarding how cultural expressions can become tools for democratic change.

Against this backdrop, the present study aims to shed light on how comics flow from one of the central producers of comic art in the global North and in the world, namely, the Francophone space (Grove 2010), are selected and translated in a peripheral cultural space of the North, namely, Sweden. An exploration of how a peripheral position filters the vast production from a central cultural space with a colonial history, and that includes comic art from transnational arenas, as well as from an Asian center like Japan, offers an overview of how the periphery makes use of its agency to promote the global South, decolonial perspectives, and marginalized voices. In addition, the longitudinal characteristics of the data reveal the evolution of filtering practices overtime. Thus, the overall interrogation concerns the following inquiries: Which categories of languaging and diversity are promoted in the timespan 1900-2020, and how is a democratic approach to international cultural exchanges and translation reflected in translation practices? Methodologically and analytically, such a study calls for a quantitative and diachronic approach with the potential to report on overall patterns and developments overtime. The results constitute the platform and context for further qualitative studies with the potential to deepen the quantitative picture, by nuancing, confirming, or disputing the analyzes of examples that emerge and are presented below. 


\section{Methodological Stages and Distant Readings of the Data}

The main data on imported comics translated into Swedish and originally created in French language varieties during the timespan 1900-2020 is extirped from a larger data set in the project Agency of the Periphery (APer). APer's overall aim is to observe how cultural peripheries contribute through their practices and strategies to the redistribution of power, prestige, and identitypositionings on literary arenas across the global South and the global North. This larger data set is based on Swedish translations of Francophone publications extracted from the Swedish national database Libris, tasked with registering everything published in Swedish. The data has been classified according to categories regarding, for example, title in French and in Swedish, date of original publication and translation, authorship, origin of authors, and library classification/s, and includes all translations from French to Swedish during the focused timespan, thus a variety of genre categories. ${ }^{3}$

The comic translations have been isolated in the overall data through a search for publication posts classified under Hci, which is the Swedish library system SAB's code for comics. In SAB's tree-like system, Hci is a sub-class of the letter $\mathrm{H}$ that designates literature in a broad sense, hence, forming an argument for treating different comic genres as related to literature. The classification code Hci was first mentioned in the fourth edition of SAB, published in 1956. To some extent, libraries have continuously added the classification Hci to items belonging to comics and published before widespread implementation of the code. ${ }^{4}$ Given that the reliability of these practices is difficult to verify, some possibly influences can be expected in analysis of the available data. However, the patterns that emerge from isolating items with the classification code Hci offer sufficient indications of how incoming flows of comics from French languaging spaces have developed.

A supplementary challenge in the data concerns the authorship of comic art albums. These are often produced in collaboration between script writers and illustrators. There are complete author-illustrators who work alone

3 The main part of the data has been listed by Dr. Bo Ekelund (Stockholm University), while Dr. Elisabet Bladh (Gothenburg University) has been responsible for the years 2005-2015. I have augmented the data with comic art references for the period 2015 to July 2020. The data for the year 2020 is up to the month of July. However, even though the complete translation rate for this year was not available for the purposes of the present study, individual publications appearing during the first seven months of 2020 confirm and elucidate patterns identified in the overall data. Bladh and Ekelund have given permission for my use of the data for this study.

4 Johan Hermfelt, Swedish National Bibliography, National Library of Sweden. Personal communication, July $7,2020$. 
on projects, while teams composed of two to four persons are also common, and, regarding persistent series, such as Tintin and Asterix, the team membership changes over time. In addition, author-illustrators frequently make use of pseudonyms, such as Peyo (Pierre Culliford), Moebius (Jean Girard), and Hergé (George Remi), contributing to creating a distance between the persona and the artist. These complex authorship features are not necessarily considered, either in Libris, or in the project Aper's data set. Consequently, as an initial analysis of the data has revealed, the consistency with which author-illustrators have been registered is not completely reliable. For this study, while the lack of exact information about teams of author-illustrators for some publications does not influence the overall picture of incoming flows overtime, it could possibly affect the visibility of certain comics collaborators.

In the initial phase, the data is exploited through methods used in "distant reading" (Moretti 2013), in opposition to "close reading" which remains the predominant method in literary studies. This methodological procedure follows the circulation and evolution of literary art forms across time and space, with the purpose to observe how they are established and become shaped by the adoption and consumption on different cultural markets. In this specific case, the flow over time is limited to Francophone comic art publications from various geographical spaces to Swedish languaging spaces. With the objective to reach a thorough understanding of a storytelling format and of a specific work, Moretti (2013) suggests a distancing from the text with its various modalities and content, and a focusing on broader patterns. This procedure allows for capturing the development and spread of a genre, such as the novel in the case of Moretti's work. In order to capture the relationship between centers and peripheries, this study is limited to the spread of a medium with its various genres from central French languaging spaces towards a peripheral one, i. e. the Francophone comic art forms' entrance on the literary market in the nation-state of Sweden.

Through a progressive procedure, the study closes in on identified patterns in the quantitative data, and on specific works representing thematic trends in the incoming flows of translated Francophone comics to Sweden. An attempt to read the languaging in selected volumes will concentrate the analytical focus to an overall level of negotiations of genre norms, as well as norms in society that relegate specific groups to marginalized positions. Languages and cultures that come into play within the frame of comics and the Francophone space, and that enable the materializing of diverse voices within and between albums are considered through multimodal features used in comic art creative languaging. 


\section{Changing Global Perspectives in the Francophone Comic Flows Towards Sweden During the Time-Period 1900-2020}

In this section, quantitative results of my analysis are presented from a "distant reading" perspective (see "Methodological stages and distant readings of the data"), where the position of the Francophone comic art market in relation to Sweden are outlined (see the sub-section "The Francophone position on the Swedish comic art market"). The second sub-section, "Establishing genre norms and creating potentials for renewal", focuses on the most frequently translated author-illustrators in the data, while observing prevailing aesthetic norms, and patterns that indicate a renewal. The third sub-section "Emergent diverse languaging across the millennium shift: 1991-2020" focuses on the turn of the last century and trends in production and translation during this specific period. The conclusion section summarizes the evolution of translation practices and strategies in the overall data and discusses how the periphery creates agency to define a medium and its genres and promote cultural relationships on a global scale.

\section{The Francophone Position on the Swedish Comic Art Market}

The collected data comprises of 1361 comic publications translated from French into Swedish between 1900 and 2020, which corresponds to about 10 percent of all categories of translations from French in the larger data set. This is to be compared to the position of comic art in the general flow of incoming literature from different languaging spaces. In fact, in 2019, comic art occupied only one percent of all literature translated into Swedish. Among publications originally published in Swedish during the same year, the relation is identical (National Library of Sweden 2020). The modest number of comic productions underscores the marginalized position of a medium with its genres in the publishing field, but not necessarily reading practices among citizens. As described in the Swedish national report Läsarnas marknad, marknadens läsare [Eng: The readers' market. The market's readers] (Warnqvist 2012), the younger readership increasingly demands for visual languaging. In addition, national comic fairs, such as Stockholm international comics festival (launched in 2012 on the basis of previous versions that date back to 1998), AltCom (launched in 2004), Seriefest (launched in 2004), and Uppsala Comics (launched in 2012), bear witness to a steadily raising interest in comics in Sweden. 
The gap between the number of translations from French and the share of comics on the national publishing market indicates that the comic art offer in Swedish is relatively dependent on Francophone productions, and that comic art's status in the mediation of texts between Francophone spaces and Sweden seems to be high. Moreover, French language is, after English language, the second most important language for literary translation in Sweden (Heilbron 1999). This central position is strengthened by a comparison with the importation of Anglophone comic art. In fact, comics does not occupy such a crucial place in the translation flows from English to Swedish, as from French to Swedish language varieties (National Library of Sweden 2020). Consequently, it is possible to consider French language varieties, and not Anglophone ones, as hyper-central with regards to the Swedish comic art market. This result indicates the agency of the periphery, and its power to challenge prevailing hegemonies of global cultural production, in this case, with regards to comics.

Figure 1 "Flows of Francophone comics in three time periods", presents the variation in incoming flows to Sweden across three time-periods and illustrates the overall view of the progressive accumulation of Francophone comics in Swedish translation. The first period corresponds to the first half of the 2oth century, during which comics developed as a form of creative and often satirical languaging internationally (Falardeau 2000). Francophone examples are missing during this time-period, which contrasts with the French language's contemporary hyper-central position. However, the American-English comics hero, Tarzan, created by the author-illustrator Edgar Rice Burroughs, figures in translations from 1944 onwards. In addition to the stereotyping of named-groups in the global South, such as Arabs and Africans, the explicit racism in the aesthetic employment of "savagery" throughout the episodes,

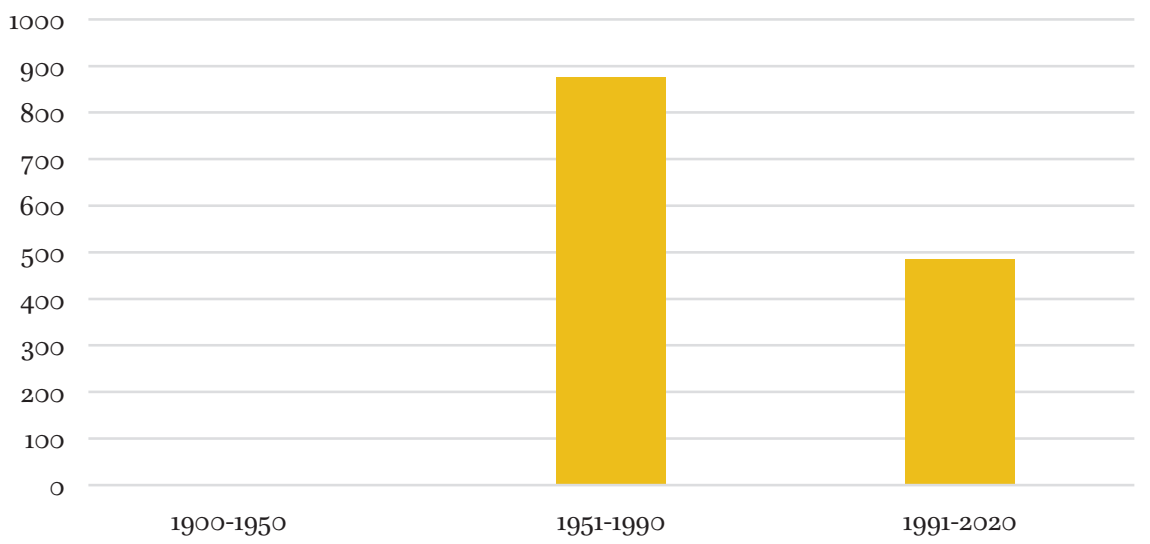

FIGURE 1 Flows of Francophone comics during three time-periods 
is hardly mitigated by the inherent critique of white civilization (Carey-Webb 1992). As observed in-depth by Carey-Webb (1992), this globally circulating narrative comprises of several common denominators with "permanent literature" (Achebe 1977) taken seriously by the academic establishment, such as Conrad's Heart of Darkness (1899). The presence of Tarzan in the Swedish context in the very beginning of local developments of comic translations and a comics market, points to the overwhelming force of a storytelling tradition of unequal power positions between racial groups. This tradition can be observed as the source of an often-repeated representation in the popular culture of jungle adventures and colonial dramas, where black identity is limited to the primitive native, whether noble or savage (O'Brien 2017).

The 196o's is the decade when Hergé's (George Remi) adventures of Tintin were introduced in Swedish, which led to a steady flow of new translations and re-editions that the data bear witness to. Consequently, the Hergé authorship is deeply rooted in the Swedish context. As in Tarzan, racist and colonial worldviews are frequent in the stories about Tintin, which has been observed by several scholars (see, for example, Dunett 2009 and Mountfort 2012). A northern exotifying gaze on the Other is continuously transferred to Sweden through this impressive production. The 1970's and 1980's contain exceptions, where representations of named-groups from outside Europe and the global North are allowed to be nuanced and intellectually complexified. An early example is created by the author Greg (Michel Louis Albert Regnier) and the illustrator Hermann (Hermann Huppen), through the introduction of the personage Toby "Black Face" in the cowboy series Comanche (1972) [Eng: Comanche 2017; Swe: Comanche 2016-2017, 3 volumes including 11 albums]. Another example from the same moment in time is the album Les Éthiopiques (1972-1973) [Eng: The Ethiopian 2016; Swe: Etiopierna 2010] in the series about the protagonist Corto Maltese, created by Hugo Pratt, where the reader meets the intriguing black character Cush (Strömberg 2012). It is notable that these albums are not accessible in Swedish before the 21st century. By contrast, the sole authorillustrator François Bourgeon appears with his series Les passagers du vent (1st series, 1979-1984) [Eng: The Passengers of the Wind] with the Swedish title, Resande med vinden, already in 1981. One album, Le bois débène (1984) [Eng: Ebony in the Cargo; Swe: Ebenholts i lasten 1984] represents life on board of a slave ship, including insightful portraits of both black and white people, while formulating an unambiguous critique of colonial practices and the slave trade.

The evolution of Francophone comic art towards a genuine artistic vein that includes self-expression and critical societal analysis is reflected during the second time-period (195-1990), that covers the postwar era until 1990. Translations consistently increase during this time span, pointing towards 
the expansion of Francophone comics world-wide. The division of the two-last time-periods is motivated by previous results in literature studies (Burnautzki 2017; Cazenave 2005; Halen 2008; Lindberg 2014) highlighting that Francophone authors originating from outside Europe tend to circulate on a global scale from the 199o's onwards. The hypothesis is that a similar tendency can be identified in the international circulation of comics. In addition, the 199o's are marked by society's entrance into the digital era, which contributes to a shift regarding literature as such, cultural hegemonies, and views on ex/ inclusive communicative practices world-wide. With the aim to problematize and disentangle the (non)-visibility of non-European and marginalized voices and perspectives in the translation flows, the next sub-section offers an overview of the most frequently produced author-illustrators in the data.

\section{Establishing Genre Norms and Creating Potentials for Renewal}

Table 1 "Frequency of author-illustrators in the data" illustrates the most frequent names referred to in the data in relation to individual comic publications. Names are labelled generically as "author-illustrators" in the table, as they can represent the author, the illustrator, or both, depending on how precise the cataloguing has been initially, and whether the creator is a sole author-illustrator or not. The works listed in connection to the author-illustrators are the most prominent series or albums among Swedish translations that the author-illustrators have been engaged in.

The number of occurrences of specific Francophone author-illustrators between 1900 and 2020 offers information regarding how the nation-state of Sweden selects, rewards, and legitimates authorships and categories of comic art (see Table 1). For example, the most frequent author-illustrators $(50<>150$ occurrences) represent the thematic vein of adventures that are often humorous and target children and young readers, such as the worldwide known series of Tintin and Asterix (see the two last columns in Table 1). The consistent production of Francophone long-running series in Swedish has led to public visibility, and, consequently, genres of comic art on the local market are inevitably defined by their languaging features. As indicated in table 1, the author-illustrators with highest frequency-such as Hergé and Morris (Maurice de Bevere) who have more than 100 translations in Swedish-are principally from the Belgian comic art market. These author-illustrators are stylistically associated either with la ligne claire [the clear line], reflecting the readability of the image, and the neat and sober narrative structure, such as in Tintin, or with the caricatural and humoristic style adopted in, for example, Spirou (Deyzieux 2008). 
TABLE 1 Frequency of author-illustrators in the data

\begin{tabular}{|c|c|c|c|c|c|}
\hline $\begin{array}{l}\text { Author/illustrator } \\
\text { frequency } \\
\mathbf{1 0 < > 2 0}\end{array}$ & $\begin{array}{l}\text { Author/illustrator } \\
\text { origin r and } \\
\text { example r of } \\
\text { album/series title }\end{array}$ & $\begin{array}{l}\text { Author/illustrator } \\
\text { frequency } \\
\mathbf{2 0}<>\mathbf{5 0}\end{array}$ & $\begin{array}{l}\text { Author/illustrator } \\
\text { origin r and } \\
\text { example r of } \\
\text { album/series title }\end{array}$ & $\begin{array}{l}\text { Author/illustrator } \\
\text { frequency } \\
50<>150\end{array}$ & $\begin{array}{l}\text { Author/illustrator } \\
\text { origin and } \\
\text { example of } \\
\text { album/series title }\end{array}$ \\
\hline Batem (Luc Collin) & $\begin{array}{l}\text { Belgium Congo } \\
\text { Marsupilami }\end{array}$ & Raoul Cauvin & $\begin{array}{l}\text { Belgium } \\
\text {-Spirou } \\
\text {-Les Tuniques } \\
\text { bleues }\end{array}$ & $\begin{array}{l}\text { Derib } \\
\text { (Claude de } \\
\text { Ribaupierre) }\end{array}$ & $\begin{array}{l}\text { Switzeralnd } \\
\text { Yakari }\end{array}$ \\
\hline $\begin{array}{l}\text { Alejandro } \\
\text { Jodorowsky }\end{array}$ & $\begin{array}{l}\text { France Chili } \\
\text { Bouncer }\end{array}$ & $\begin{array}{l}\text { Jean-Michel } \\
\text { Charlier }\end{array}$ & $\begin{array}{l}\text { Belgium } \\
\text { Blueberry. }\end{array}$ & André Franguin & $\begin{array}{l}\text { Belgium } \\
\text {-Spirou } \\
\text {-Gaston } \\
\text {-Marsupilami }\end{array}$ \\
\hline Claire Brétecher & $\begin{array}{l}\text { France } \\
\text { Les frustrés. }\end{array}$ & Pierre Christin & $\begin{array}{l}\text { France } \\
\text { Valérian }\end{array}$ & René Goscinny & $\begin{array}{l}\text { France } \\
\text { Asterix }\end{array}$ \\
\hline $\begin{array}{l}\text { Jean-Claude } \\
\text { Fournier }\end{array}$ & $\begin{array}{l}\text { Erance } \\
\text { Spirou }\end{array}$ & Philippe Tome & $\begin{array}{l}\text { Belgium } \\
\text { Spirou et Fantasio }\end{array}$ & $\begin{array}{l}\text { Hergé } \\
\text { (George Remi) }\end{array}$ & $\begin{array}{l}\text { Belgium } \\
\text { Tintin }\end{array}$ \\
\hline François Craenhals & $\begin{array}{l}\text { Belgium } \\
\text { Chevalier ardent }\end{array}$ & & & $\begin{array}{l}\text { Morris } \\
\text { (Maurice de } \\
\text { Beyere) }\end{array}$ & $\begin{array}{l}\text { Belgium } \\
\text { Lucky Luke }\end{array}$ \\
\hline Roger Leloup. & $\begin{array}{l}\text { Belgium } \\
\text { Yoko Tsuno }\end{array}$ & & & $\begin{array}{l}\text { Peye } \\
\text { (Pierre Culliford) }\end{array}$ & $\begin{array}{l}\text { Belgium } \\
\text { Les Schtroumpts }\end{array}$ \\
\hline $\begin{array}{l}\text { Raymond } \\
\text { Macherot }\end{array}$ & $\begin{array}{l}\text { Belgium } \\
\text { Chlorophylle }\end{array}$ & & & & \\
\hline Jacques Martin & $\begin{array}{l}\text { France } \\
\text { Alix }\end{array}$ & & & & \\
\hline Jacques Tardi & $\begin{array}{l}\text { France } \\
\text { Les } \quad \text { aventures } \\
\text { extra-ordinaires } \\
\text { d'Adele Blanc-sec }\end{array}$ & & & & \\
\hline Albert Uderze & $\begin{array}{l}\text { France } \\
\text { Asterix }\end{array}$ & & & & \\
\hline
\end{tabular}

With regards to the format, the Franco-Belgian album tradition is imposed as a model through these reproductions, which has marked the conceptualization of comics in Sweden (Arnerud Mejhammar 2017; Labio 2017). It is significant that the same tendency is confirmed among author-illustrators occurring with less frequency $(20<>50$ occurrences, see Table 1$)$. Belgian author-illustrators are popular in this group as well, though Pierre Christin, the French creator of the heroes Valérian and Laureline, Valérian et Laureline (1967) [Eng: Valérian and Laureline 1981; Swe: Linda och Valentin 2014-2020, 15 volumes], is part of this data as well. ${ }^{5}$

The overview of author-illustrators who appear with a frequency between 10 and 20 occurrences $(10<>20$ occurrences, see the first column in Table 1) highlights a more diverse selection in comparison to the columns that list the most frequently occurring author-illustrators. Firstly, French author-illustrators are offered more visibility in this group, and cultural spaces beyond Europe are partly represented through comic artists, such as Alejandro

5 For this series the French team was composed of Christin (scriptwriter), Jean-Claude Mézière (illustrator), and Évelyne Tranlé (colorist). The example shows how cataloguing practices and citations could serve the purpose to offer visibility to female comic artists involved in the creative team. 
Jodorowsky who has a Chilean background, and Batem (Luc Collin) with Congolese origins. Secondly, Bretécher emerges in this frequency as the only female author-illustrator among the most translated ones in the data. It is also in this group that we find the Belgian author-illustrator Roger Leloup, who created the Japanese female heroine and electronic engineer Yoko Tsuno already in 1972 [Eng: The Adventures of Yoko, Vic and Paul 1989; Swe: Yoko Tsuno 1979-2020, 18 volumes].

In addition to these examples that introduce attempts to create a cultural and gender balance in the selection of translations, the French author-illustrator Jacques Tardi appears in the group, with his work marked by multiple illustrations and adaptions of French classic literature, such as Céline, Jules Verne, and Proust, as well as of historical material, not least his visual stories that retrace the First World War (Chimot 2010). Intentionally or not, the historical, literary, and intellectual verve observable throughout Tardi's work serves the purpose of reinforcing northern perspectives in popular cultural production. In addition, Tardi's fantastic (in opposition to realistic) original series about Adèle Blanc-Sec, Les aventures extraordinaires d'Adèle Blanc-Sec (1976-2007, 9 volumes) [Eng: The Most Extra-Ordinary Adventures of Adèle Blanc-Sec 1990; Swe: Adeles extraordinära äventyr 1979-1986, 7 volumes] brings Tardi to a higher level of global circulation, especially through the film adaption (2010) with the same title, directed by Luc Besson. Thus, Tardi's authorship is an example of how cultural capital of the global North steadily gets confirmed and circulated throughout the world, towards peripheries in the global North as well as in the South, by means of different media.

The asymmetric relationship rendered visible through the data in this way raises questions regarding the impact on local and global scales of translation and mediation practices of peripheries, such as those in Sweden. In what ways could conscious selection and recognition of different categories of literature from a variety of origins challenge a hegemonic elitist conception of literature? A balanced importation, where commercial interests and a need for cultural and creative renewal are considered could, perhaps, be a forceful tool to break with the absorbing practices of cultural and languaging centers. In the case of Sweden, it is possible to identify continuous selection and recognition processes that prioritize author-illustrators who are already established locally and internationally, i. e. those who circulate on a global scale, which most probably contribute to cementing hegemonies in the "world republic of letters" (Casanova 2004) and hinder the evolution of culturally diversified comic production in the local field. 


\section{Emergent Diverse Languaging Across the Millennium Shift: \\ 1991-2020}

As presented in Figure 1 "Flows of Francophone comics across three time periods", translation flows drop during the timespan 1991-2020 to almost half of the publications made available in Swedish during the former period (19511990) and are stabilized between about 10 to 20 publications per year in the 21st century. However, the decrease in translations from French language varieties does not correspond to a stagnation regarding the development towards a more diverse selection. On the contrary, the initial hypothesis that transnational author-illustrators are emerging during the timespan seems to be confirmed. In parallel, diversified creative projects and perspectives on the world are appearing in the data.

During the previous timespan (1951-1990), principally two female authorillustrators have been identified, namely Bretécher and Beaunez. In the 21st century, female author-illustrators become more present in the comics field internationally, which is reflected in the Swedish translation flow from Francophone languaging spaces. In table 2 "Female author-illustrators in Swedish translation: 1991-2020", female Francophone author-illustrators during the timespan related to the millennium shift are listed. It is significant that the first translation of a woman's work during this time-period occurs in 2005, when the Iranian author-illustrator Marjane Satrapi's Persepolis (Fre: 2000-2003) was published in Swedish. This moment in time corresponds to a recognition of local female author-illustrators in the Swedish comics field (Lindberg 2016), even though no re-editions of Bretécher or Beaunez have been identified.

In total, 12 female authors are represented with 40 publications (see Table 2), of which several are audio-versions of the original translation. These numbers correspond to almost eight percent of all comic translations during the focused time-period. As indicated above, this extreme asymmetry could partly be improved if female collaborators on comic projects with male main authors became more visible in the catalogued references. Nevertheless, the share of Francophone female author-illustrators in Swedish translations has increased considerably in comparison to the time-period 1951-1990, where hardly two percent of the original works were authored and/or illustrated by women. Moreover, six of the female author-illustrators in table 2, or half of them, originate from outside the Franco-Belgian axe, from cultural spaces both in the global South and in the global North. Kan Takahama forms an exception, since this Japanese mangaka is active in Japan and not in a Francophone space, even though her work has been translated into Swedish from the French version. 
TABLE 2 Female author-illustrators in Swedish translation: 1991-2020

\begin{tabular}{|c|c|c|c|}
\hline $\begin{array}{l}\text { Female author- } \\
\text { illustrator and } \\
\text { origin }\end{array}$ & $\begin{array}{l}\text { Number of } \\
\text { publications } \\
\text { in Swedish }\end{array}$ & $\begin{array}{l}\text { Title of main } \\
\text { publication in } \\
\text { French }\end{array}$ & $\begin{array}{l}\text { Title of main in } \\
\text { Swedish }\end{array}$ \\
\hline $\begin{array}{l}\text { Zeina Abirached, } \\
\text { Lebanon }\end{array}$ & 1 & $\begin{array}{l}\text { Mourir, partir, } \\
\text { revenir, le jeu des } \\
\text { hirondelles }\end{array}$ & $\begin{array}{l}\text { Svalornas lek: Dö, } \\
\text { resa, återvända }\end{array}$ \\
\hline $\begin{array}{l}\text { Marguerite Abouet, } \\
\text { Ivory Coast }\end{array}$ & 7 & Aya de Yopougon & $\begin{array}{l}\text { Aya från } \\
\text { Youpougon }\end{array}$ \\
\hline $\begin{array}{l}\text { Arsenault, Isabelle } \\
\text { \& Britt, Fanny, } \\
\text { Quebec }\end{array}$ & 1 & $\begin{array}{l}\text { Jane, le renard et } \\
\text { moi }\end{array}$ & Jane, räven och jag \\
\hline $\begin{array}{l}\text { Pénélope Bagieu, } \\
\text { France }\end{array}$ & 1 & $\begin{array}{l}\text { California } \\
\text { Dreamin' }\end{array}$ & $\begin{array}{l}\text { California } \\
\text { Dreamin' }\end{array}$ \\
\hline $\begin{array}{l}\text { Chloé Cruchaudet, } \\
\text { France }\end{array}$ & 2 & $\begin{array}{l}\text { Mauvais genre: } \\
\text { d'après La } \\
\text { garçonne et l'as- } \\
\text { sassin de Fabrice } \\
\text { Virgili \& Danièle } \\
\text { Voldman }\end{array}$ & $\begin{array}{l}\text { Lånat kön: efter } \\
\text { La garçonne } \\
\text { et l'assassin av } \\
\text { Fabrice Virgili \& } \\
\text { Danièle Voldman }\end{array}$ \\
\hline $\begin{array}{l}\text { Céline Fraipont, } \\
\text { Belgium }\end{array}$ & 8 & $\begin{array}{l}\text { Au château de } \\
\text { Crotte de maille }\end{array}$ & Slottet Stinkadus \\
\hline $\begin{array}{l}\text { Véronique } \\
\text { Grisseaux, } \\
\text { France }\end{array}$ & 3 & $\begin{array}{l}\text { Meilleures } \\
\text { ennemis }\end{array}$ & Bästa vänner \\
\hline $\begin{array}{l}\text { Nancy Peña, } \\
\text { Spain }\end{array}$ & 3 & Le chat du kimono & $\begin{array}{l}\text { Katten och } \\
\text { kimonon }\end{array}$ \\
\hline $\begin{array}{l}\text { Lisa Mandel, } \\
\text { France }\end{array}$ & 1 & $\begin{array}{l}\text { Princesse aime } \\
\text { princesse }\end{array}$ & $\begin{array}{l}\text { Prinsessa älskar } \\
\text { prinsessa }\end{array}$ \\
\hline $\begin{array}{l}\text { Julie Maroh, } \\
\text { France }\end{array}$ & 1 & $\begin{array}{l}\text { Le bleu est une } \\
\text { couleur chaude }\end{array}$ & $\begin{array}{l}\text { Blå är den var- } \\
\text { maste färgen }\end{array}$ \\
\hline $\begin{array}{l}\text { Marjane Sapatri, } \\
\text { Iran }\end{array}$ & 11 & Persepolis & Persepolis \\
\hline $\begin{array}{l}\text { Kan Takahama, } \\
\text { Japon }\end{array}$ & 1 & Kinderbook & $\begin{array}{l}\text { Kinderbook: } \\
\text { Serier för sorgsna } \\
\text { barn }\end{array}$ \\
\hline
\end{tabular}


Takahamas work, Kinderbook (2004) has been translated with the subtitle "Comics for sad children" in Swedish, which is slightly misleading, since the album only adopts a child's perspective to tell short stories about the adult world that do not primarily target young readers. In addition, the novel L'amant (1984) [Eng: The Lover 1992; Swe: Älskaren 1985], by the French prestigious author of la nouvelle vague [the New Wave] Marguerite Duras, is well known and a consistent number of translations and reeditions of Duras' work exists in Swedish (Aronsson 2015). Therefore, it is quite surprising that Sweden has not opted for the translation of Takahama's adaption of the novel. Takahama's sensitive remediation of the story bridges the gap between comics and literature, just as it highlights that female author-illustrators engage in the intellectual vein, previously mentioned in relation to male author-illustrators (see section "Introduction. Purpose and aim"). As in the case of Tardi, the Swedish periphery's recognition of the link between canonized Franco-European literature and comic art authorship, could increase Takahama's visibility and status in Swedish and international comics arenas.

The increase of women in the comics field has transformed the notion of comics, since these author-illustrators refuse to conform to established (male) aesthetic norms, and bring in a new artistic sensitivity, alternative comics projects, as well as new thematic subjects. The female turn in the Francophone comics field is confirmed by the former director of La Cité internationale de la bande dessiné et de l'image à Angoulême [The international city of comics and image in Angoulême], Gilles Ciment (see Bagga-Gupta 2019; 2018 for a theoretical understanding of the concept of "turn"). Ciment (2017) states that while about 20 percent of comics author-illustrators active in France are females (which is to be compared to the eight percent of females in the Swedish importation flow), these professionals do not receive recognition in consecrating instances, such as the yearly Angoulême comics festival and its nomination processes for awards. These marginalizing practices are applied, as well, on comics produced in minor languages, particularly those associated with the global South. These practices are changing, but at a very slow pace, which motivates a closer examination of the female turn in Francophone comics.

The comics examples translated into Swedish (see table 2) highlight in more precise ways how Francophone female author-illustrators innovate regarding languaging features of comics. Zeina Abirached, for example, departs from her hometown, Beirut, with the aim to retrace the microscopic everyday life in the city in wartimes. The stylized architectural drawings of the city offer an entrance into the author-illustrator's personal interpretation of a reality outside European spaces, where strategies for survival are planned and discussed between friends and family members behind protecting walls of the 
home. This autobiographic strand is partly picked up by Marguerite Abouet. In her series about Aya, she returns to Abidjan of her childhood to depict an Africa that is far away from common representations of misery and poverty, and instead focuses on the people living in the quarter Youpogoun and on their everyday stories and dramas. Moreover, it is significant that the French bestselling author, Anna Gavalda, has written the foreword to the series about Aya. Gavalda's novels and short stories are subtly linked to Abouet's work through the theme of romantic encounters and personal imbroglios. Both authors adopt their talent for fine observations of human interaction and manage to render people's shortcomings and individual challenges with warmth and humour. Thus, the connection between literature and comics is activated once again in this clever manner; in this case, to reinforce the status of a transnational authorship connected to Africa. Abirached's and Abouet's approaches pursue a thematic autobiographic line initiated by Marjane Satrapi's retracing storytelling of her life between Teheran and Paris, displayed in the series Perspepolis (Chute 2008). Since Bretécher's unprecedented international success, Satrapi can be considered the first Francophone female within comic art to attain a significant outreach and circulation in the world, and, thereby, paving the way for other female successors. ${ }^{6}$ Not only do these female authorillustrators revisit an autobiographic strand while introducing women's life and perspectives in comics, but they also manage to reformulate views on cultural spaces in the global South through the visual storytelling of the spaces and the stories going on in such spaces. In this way, through a central language as French, artistic, and literary comic artefacts center-stage marginalized places, events, and people, and offer alternative voices and representations of the global South in the world.

Female author-illustrators from France are also present in the translation flow between 1991 and 2020, but with a different inspiration that taps into the theme of sex, society, and relationships. Gender equality, as well as female and lesbian sexuality, form innovative elements that are addressed in visualized ways in these works situated between fiction and reality. For example, Pénélope Bagieu's biographical approach retraces the life of the singer and artist Cass Elliot in the Mamas and the Papas, with the purpose to tell a story

6 As Hillary Chute (2010) powerfully reminds us, female artists have for a long time used comics to express distress, resentment, and experiences of (male) violence, as well as caustic critique of patriarchal societies. This production forms the basis and the conditions that allow for individual female author-illustrators, such as Bretécher and Sapatri, to circulate and get recognition on a global scale (see Burnautzki 2017; see also Lindberg 2018a for a model of local and global circulation). 
of a female destiny. The choice of content recalls creative endeavors among Swedish female author-illustrators in the 21st century, such as in the work of Liv Strömquist, who systematically put afore historical personalities, both men and women, or Loka Kanarp, with her volume Pärlor och Patroner (2009) [Eng: Pearls and Bullets] that presents portraits of historical women.

The French author-illustrators Lisa Mandel and Julie Maroh, in their turn, focus on love between women, suggesting that 21st century female comics creativity also challenge the male heteronormative dominance of the theme sex, society, and relationships. Maroh's album, Le bleu est une couleur chaude (2010) [Eng: Blue is the Warmest Colour 2014] has enjoyed considerable attention inside and outside France through the adaption of the album into a film, La Vie d'Adèle (2013) [Eng: Blue is the Warmest Colour 2013; Swe: Blå är den varmaste färgen 2013], by director Abdellatif Kechiche. With Chloé Cruchaudet's Mauvais genre (2013) [Eng: Deserter's Masquerade 2017] the queer theme is underscored through the adaption of the tragic real-life story about Paul Grappe and Louise Landy, documented in the book, La garçonne et l'assassin (2011) [Eng: The Garçonne and the Murderer] by Fabrice Virgili and Danièle Voldman. During the First World War, Paul deserts from the front and is obliged to disguise himself as a woman to avoid prison. Forced to live as a transvestite for 10 years, his life with Louise takes multiple unexpected turns. These examples highlight alternative worldviews opposed to northern normative ways of framing culture, identity, gender, sexuality, and historical events in mainstream comic flows to Sweden. In addition, they challenge the "male gaze" (El Refaie 2012) that forces women to see themselves through male eyes (Berger 1972).

Renewed translation practices and strategies in Sweden during this time-period promotes a reconfiguring of representational power that benefit, as well, avant-garde creative endeavors among male author-illustrators from different spaces. An increased awareness of Francophone comics as inclusive of voices from the global South has served, for example, the French author-illustrator Riad Sattouf. His work, L'Arabe du futur (2014-2018, 4 volumes) [Eng: Arab of the Future 2015; Swe: Framtidens arab 2017-2021, 4 volumes] has recently been translated into Swedish. Along the same line as the above-mentioned Francophone female author-illustrators, Sattouf adopts an autobiographical approach when he retells his childhood between European and Middle Eastern countries, such as Lebanon, Libya, and Syria. Stylistically, he makes use of colours as a technique to indicate in which geographical space the different passages take place, and he does not hesitate to depict both European and Arabic people in satirical ways. His work has been published in more than 20 European languages, which confirms an international 
interest in comic stories introducing perspectives that challenge Eurocentric content norms, while excluding reception in languaging spaces outside northern boundaries. Except for Sattouf, few male author-illustrators during this time-period originate from outside Europe, even though the Belgian author-illustrator Jung (Jung Henin), adopted from Korea, is noteworthy with his autobiographical series Couleur de peau: miel (2006-2016, 4 volumes) [Eng: Skin Colour: Honey 2007; Swe: Hudfärg: honung 2015-2017, 2 volumes], in which he tells the story about his own adoption by a Belgian family.

However, European author-illustrators originating from non-Francophone spaces are increasing in Swedish translations during this time-period, indicating the attraction of the Francophone central position in the comics field. For example, the Norwegian author-illustrator Jason (John Arne Sæterøy) has made a name internationally with his sharp and cynical stories in the French language. Spanish author-illustrators Enrique Fernandez, with the work Contes de l'ere du cobra (2012-2013, 2 volumes) [Eng: Tales from the Cobra Age 2018; Swe: Sagor från kobrans tid 2014-2015, 2 volumes] and Juan Diaz Canales, with the hardboiled series about the detective Blacksad (2000-2013, 5 volumes) [Eng: Blacksad 2010; Swe: Blacksad 2006, 3 volumes], also figure among 21st century representatives of comics published in French and translated into Swedish. Regarding form and content, male author-illustrators popularly pursue the Franco-Belgian aesthetic line from the postwar era instead of breaking with its genre norms. Diaz Canales' creation of Corto Maltese's zoth adventure Sous le soleil de minuit (2015) [Eng: Under the Midnight Sun 2016. Swe: Under midnattssolen 2016] is a clear indication of this tendency. Resembling Hugo Pratt's storytelling practices, the author-illustrator essentially inserts male and white historical personalities into the plot, while letting the Afro-American midwife, feminist, and ancient slave, Jenny Prentiss, as well as the Japanese former prostituted and feminist, Waka Yamada, represent marginalized positions in the outskirts of the story.

The French author-illustrator, Fabien Nury, in his turn, is translated continuously from 2013 onwards, both with his series on global North historical events in the 2oth century, and with his series Katanga (2017-2019, 3 volumes) [Eng: Katanga 2018. Swe: Katanga, 2017-2019, 3 volumes], situated in Africa. Katanga retraces the violent history of mercenary in Congo-Kinshasa and presents a subtle critique of France's postcolonial presence on African terrain. This category of explorations of the world outside Europe, underpinned by societal criticism, is also recognizable in the French author-illustrator Guy Delisle's documentary comic work. Delisle's stays abroad by challenging cultural spaces such as Pyongyang, Burma, and Jerusalem in the global South, often alongside his wife who works for Les médecins sans frontiers; he generates fine visual and textual 
observations of everyday life from an outsider's perspective. Sweden has translated three of these albums between 2013 and 2014 and awarded Pyongyang (2003) [Eng: Pyongyang: A Journey in North Korea 2007. Swe: Pyongyang 2014] the best translated comics album in 2014 (see the website Urhunden>pristagare).

In summary, translation practices in Sweden of Francophone comics overtime confirm an obvious diversification of creative projects in the 21st century. The last decades present multifold examples of ways of seeing and going beyond patriarchal and heteronormative norms, as well as Euro-centric cultural boundaries and traditional comic content. However, these examples remain dominated by European author-illustrators, who, in parallel to their privilege of creational freedom, sustain Franco-Belgian aesthetic and content norms in the comic art field.

\section{Conclusion: The Role of the Periphery for Inclusive Translation Practices}

Translation flows of comics from Francophone spaces towards Sweden go through several stages and transformations during the time-period 1900-202O. Until 1959, comics in French language varieties seem not to reach out to the Swedish periphery at all, while the following decades are marked by a steady increase of translations. Popular Belgian productions introduced in Sweden at an early stage and with an extraordinary longevity, such as Tintin and Asterix, represent the basis of the Francophone flow over time. This is also profoundly problematic, in view of the centrism in these stories that adopts an exotifying and sometimes racist approaches to other cultures.

The importation of Francophone comics stabilizes around the millennium shift to 10 percent of all Francophone literature, which positions the Francophone spaces as hyper-central with regards to the comics field in Sweden. In this way, through the periphery's translation practices and strategies, hegemonies in international cultural exchanges are challenged. In addition, by the means of French language varieties and Francophone production centers, author-illustrators from the margins-i. e. those identifying with cultures and languages either outside Francophone spaces or outside the global North-increase their possibilities to circulate on an international scale. (Lindberg 2020) This trend is concretely manifested in the 21st century, by Swedish translation endeavors of author-illustrators with diverse backgrounds. The hypothesis put forward initially regarding the time-periods consisted of the idea that Francophone author-illustrators from the global South 
would appear in the data in 199o's, as is the case in the literary field. However, in the comics field this change emerges later, and becomes notable first around 2005. It is worth underscoring that this momentum coincides with a recognition of female Swedish comics author-illustrators, as well as of Swedish immigrant literature, during a period of increased immigration to Sweden. The breakthrough of diverse voices on the cultural market, and in the translation flows, is paired with a promotion of Francophone female author-illustrators in Swedish translations, equally from the global South and the global North. (Lindberg 2017) This feature in the data indicates that selection processes of comic art intended for translation in Sweden have seen mainly two criteria, namely, ethnicity and gender, with the purpose to include diverse voices. In addition, in the 21st century, translations of French and Belgian author-illustrators who address contexts in the global South also becoming more common; this points to a broader interest for stories that take place outside the global North.

However, during the time-period 1951-199o in the data, the translated comics are almost solely represented by white male European author-illustrators, and the comic content systematically evolves around the global North. Some exceptions, such as François Bourgeon's series Les Passagers du vent, and Bretécher's series Les Frustrés, can be considered as precursors of the 21st century's more diverse Francophone comic flows.

In conclusion, the results present indications that established notions about the various genres of the comic art medium tend to prevent diverse voices from emerging within the field, as well as hindering innovation and freedom of creation. This is further confirmed by the importation flow during the time-period 1991-2020. Emerging Francophone author-illustrators from the global South and female author-illustrators in the 21st century break with norms and traditions within the comics field in their attempts to introduce original creations. This includes multimodal, particularly visual techniques to represent cultural spaces in the global South on an equal footing with cultural spaces in the global North. However, they still seem to be bound to representing their own personal experiences, limited to some themes that could be summarized as: autobiography, children's literature, and gender criticism, while white male colleagues continue to produce comics in all these areas, and in areas where female and global South comics artists continue to be relatively invisible, for example the branch of mainstream adventures series.

Nevertheless, it is undeniable that the 21st century's Francophone comics flow to Sweden presents a relative diversity of comic art productions that blur demarcation lines between sub-fields, as well as between cultures and 
languages. (Lindberg 2019) One can thus say that Sweden, with its peripheral position in the field, has made use of its agency to promote a selection of comic art mainly from Francophone spaces, which has served the purpose to define the medium and its genres on its local market. The present study offers examples of overall results with regards to these local translation practices and strategies, how these vary over time, and impact on the offer of comic art in Swedish. In fact, contemporary Francophone comics on the Swedish peripheral market present a dynamic diversity regarding cultures and languaging features that is not always visible in the importation of Francophone literature. Comic art as a medium thus constitutes a growing means for mediating fiction with the potential to challenge prevailing societal norms and worldviews, as well as providing established aesthetic features of what comics are and can be. The diverse forms and contents included in the medium makes it a forceful tool for contemporary storytelling from a range of cultural and languaging spaces to circulate in translation. Hopefully, translation studies can further contribute to a revitalization of practices and towards a change, allowing for a generation of translated comics in Sweden from different cultural peripheries and minor languages that can become accessible. Such a change would most probably be decisive for improved democratic views on the world; on where and how culture is created, and by whom.

\section{References}

Arnerud Mejhammar, Kristina. "Tecknade serier för vuxna i Sverige från 196o-tal till 2016 - en introduktion." In De tecknade seriernas språk, edited by David Gedin, 1538. Stockholm: Gedin \& Balzamo förlag, 2017.

Aronsson, Mattias. 'Traduire dit-elle': Marguerite Duras en traduction suédoise (1947-2013)". In Médiations interculturelles entre la France et la Suède: Trajectoires et circulations de 1945 à nos jours, edited by Mickaëlle Cedergren and Sylvain Briens, 141-158. Stockholm: Stockholm University Press, 2015.

Bagga-Gupta, Sangeeta. "Learning Languaging Matters. Contributions to a Turnon-Turn Reflexivity." In Reconceptualizing Conceptions between Language, Learning and Literacy, edited by Sangeeta Bagga-Gupta, Anne Golden, Lars Holm, Helle Laursen, and Anne Pitkänen-Huhta, 103-124. Rotterdam: Springer, 2019.

Bagga-Gupta, Sangeeta. "Going beyond 'single grand stories' in the Language and Educational Sciences. A turn towards alternatives." Aligarh Journal of Linguistics 8 (2018): 127-147.

Berger, John. Ways of seeing: based on the BBC television series with John Berger. British Broadcasting Corporation and Penguin books: London, 1972. 
Berndt, Jaqueline. "Manga, Which Manga? Publication Formats, Genres, Users.” In Japanese Civilization in the 21st Century, edited by Andrew Targowski, Juri Abe, Hisanori Katō, 121-133. New York: Nova Science Publishers, Inc, 2016.

Berninger, Mark, Jochen Ecke and Gideon Haberkorn (eds.). Comics as a Nexus of Cultures: Essays on the Interplay of Media, Disciplines and International Perspectives. Jefferson, N.C.: McFarland, 2010.

Bourdieu, Pierre. "The Forms of Capital." In Sociology of Education: A Critical Reader, 2nd ed., edited by Alan R. Sadovnik, 83-95. London/New York: Routledge, [1986] 2011.

Bourdieu, Pierre. “A Conservative Revolution in Publishing." Translation Studies 1, no. 2 (2008): 123-153. Doi: 10.1080/14781700802113465.

Bramlett, Frank. (ed.). Linguistics and the Study of Comics. Houndmills, Basingstoke, Hampshire: Palgrave Macmillan, 2012.

Burnautzki, Sarah. Les Frontières racialisées de la littérature francophone: contrôle au faciès et stratégies de passage. Paris: Honoré Champion, coll. Francophonies, 2017.

Carey-Webb, Allen, 'Heart of Darkness, Tarzan', and the 'Third World': Canons and Encounters in World Literature." College Literature 19/20, no. 3/1 Teaching Postcolonial and Commonwealth Literatures (Oct. 1992-Feb. 1993): 121-141. The Johns Hopkins University Press.

Casanova, Pascale. "Consecration and Accumulation of Literary Capital: Translation as Unequal Exchange." In Critical Readings in Translation Studies, edited by Mona Baker and Siobhan Brownlie, 285-303. London: Routledge, 2010.

Casanova, Pascale. The World Republic of Letters. Cambridge, MA: Harvard University Press, 2004.

Cazenave, Odile M. Afrique sur Seine: a New Generation of African writers in Paris. Lanham, Md.: Lexington Books, 2005.

Chimot, Jean-Philippe (2010). Tardi: dessiner, illustrer. Sociétés \& Représentations, 29(1), 25-39.

Chute, Hillary. "The Texture of Retracing in Marjane Satrapi's Persepolis." Women's studies quarterly 36, no. 1/2 (2008): 92-110.

Chute, Hillary. Graphic Women: Life Narrative and Contemporary Comics. New York: Columbia University Press, 2010.

Ciment, Gilles. "Femmes dansla bande dessinée. Des pionnières à l'affaire d'Angoulême.” Bulletin des Bibliothèques de France-BBF (February 2017): 148-166.

Deyzieux Agnès. "Les grands courants de la bande dessinée." Le français aujourd'hui 2, no.161 (2008): 59-68. https://www.cairn.info/revue-le-francais-aujourd-hui-20o8-2page-59.htm

El Refaie, Elisabeth. Autobiographical Comics. Life Writing in Pictures. Mississippi: University Press of Mississippi, 2012.

Even-Zohar, Itamar. "Polysystem Studies." Poetics Today, 11, no.1 (1990): 1-261. 
Falardeau, Mira. “La naissance delabande dessinée delangue française." Communication 20, no.1 (2000): 194-213.

Falardeau, Mira. "La naissance delabande dessinée delangue française." Communication 20, no.1 (2000): 194-213.

Federici, Sandra. L'entrance des auteurs africains dans le champ de la bande dessinée européenne de la langue française (1978-2016). Paris: L'Harmattan, 2019.

Grove, Laurence. Comics in French: the European bande dessinée in context. New York: Berghahn Books, 2010.

Halen, Pierre. "A propos des modalités d'insertion des littératures dites de l'immigration ou de migrantes dans le système littéraire francophone." In Écriture migrante/ Migrant writing, edited by Danielle Dumontet and Frank Zipfel, 37-48. Hildesheim: George Olms Verlag, 2008.

Hatfield, Charles and Bart Beaty (eds.). Comics Studies: a Guidebook. New Brunswick, New Jersey: Rutgers University Press, 2020.

Heilbron, Johan. "Towards a Sociology of Translation: Book Translations as a Cultural World-System." European Journal of Social Theory 2, no. 4 (1999): 429-444.

Kennedy, Tammie M., Jessi Thomsen, and Erica Trabold. "Comics and Composition, Comics as Composition: Navigating Production and Consumption." English Faculty Publications 43, no.1 (2015): 183-200.

Kukkonen, Karin. Contemporary Comics Storytelling. Lincoln: University of Nebraska Press, 2013.

Labio, Catherine. "The Inherent Three-Dimensionality of Comics." Yale French Studies, no. 131-132, Bande Dessinée. Thinking Outside the Boxes (2017): 84-100.

Lindberg, Ylva. "The Uncapturable Contours of an Author. Ambiguous Postures in French Media of Transnational Francophone Writers Fatou Diome and Alain Mabanckou." Moderna språk, Special Issue 1 (2020): 78-113.

Lindberg, Ylva. "Våld, värme och manga. Perifer litteratur och centrala litterära kompetenser." In Svensklärarföreningens årsskrift 2019: Globalt, edited by Ulrika Nemeth och Anna Nordenstam, 75-94. Stockholm: Svensklärarföreningen, 2019.

Lindberg, Ylva. "L'(im)mobilité de l'œuvre de Melchior Mbonimpa et le refus de la world literature." Nordic Journal of Francophone Studies / Revue nordique des études francophones 1, no. 1 (2018a): 62-76.

Lindberg, Ylva. "Moving Manga: Integration and bypassing as strategies in the cases of France and Sweden." Orientaliska Studier, no.156 (2018b): 63-73.

Lindberg, Ylva and Mickaëlle Cedergren. "La lecture de la littérature francophone à la lumière d'un contexte nordique. Réflexions sur la recherche universitaire actuelle en littérature." Romanesques, no. 9 Le roman français vu de l'étranger (2017): 201-224.

Lindberg, Ylva. "The Power of Laughter to Change the World. Swedish Female Cartoonists raise their voice." Scandinavian Journal of Comic Art 2, no. 2 (Spring 2016): $3-31$. 
Lindberg, Ylva. "Le regard suédois sur les femmes écrivains de la francophonie." In Médiations interculturelles: trajectoires et circulations entre la France et la Suède de 1945 à nos jours, edited by Mickaëlle Cedergren and Sylvain Briens, 44-55. Stockholm: Presses universitaires de Stockholm, Acta Romanica, 2014.

Lindberg, Ylva. De la Belle époque à Second Life. Paris: É Pu (Cyber), 2013.

Moretti, Franco. Distant Reading. London, New York: Verso, 2013.

Mountfort, Paul. “Yellow skin, black hair ... Careful, Tintin': Hergé and Orientalism”. Australasian Journal of Popular Culture 1, no.1 (2012): 33-49.

National Library of Sweden. Nationalbibliografin i siffror 2019. Stockholm: National Library of Sweden. https://www.kb.se/om-oss/det-har-gor-vi/nationalbibliografin. html.

O’Brien, Daniel. “The Natives Are Still Restless: Black Representation in Whitened Africa from Tarzan to Mandela." In Black Masculinity in Film by Daniel O'Brien, 23-53. London: Palgrave Macmillan, 2017.

Statistics Sweden. Sveriges framtida befolkning 2018-2070. Demographic reports 2018:1. URL: https://www.scb.se/en/.

Strömberg, Fredrik. Black Images in the Comics: A Visual History. Seattle, Washington: Fantagraphics, 2012.

Wallerstein, Immanuel Maurice. World-Systems Analysis: An Introduction. Durham/ London: Duke University Press, 2004.

Warnqvist, Åsa. "Dragonball, LasseMaja och Twilight: Utgivningen av barn- och ungdomslitteratur i Sverige 2001-2010." In Läsarnas marknad, marknadens läsare: forskningsantologi utarbetad för Litteraturutredningen, edited by Ulla Carlsson and Jenny Johannisson, 295-313. Göteborg: Nordicom, 2012.

Zlatnar Moe, Maria, Tanja Žigon, and Tamara MikoličJužnič (eds.). Center and Periphery: Power Relations in the World of Translation. Ljubljana: Ljubljana University Press, Faculty of Art, Department of Translation studies, 2019. 